\title{
UJI EFEKTIVITAS EKSTRAK DAUN SAMBILOTO (A. Paniculata [BURM.F] NEES) SEBAGAI BAHAN PENGAWET ALAMI TOMAT DAN CABAI MERAH
}

\author{
Effectiveness Test of Extract of Sambiloto Leaf (A. paniculata \\ [Burm.f] Nees) as a Natural Preservative for \\ Tomato and Red Chili
}

\author{
*Widya Astuti Pusung, Paulus H. Abram, dan Siang Tandi Gonggo \\ Pendidikan Kimia/FKIP - Universitas Tadulako, Palu - Indonesia 94118 \\ Received 17 June 2016, Revised 18 July 2016, Accepted 19 August 2016
}

\begin{abstract}
Preservation synthetically or naturally is intended to extend the storability of tomato and red chili. Sambiloto (A. paniculata [Burm.f] Nees) is containing saponins that has anti-bacterial properties, therefore can be used as a preservative. The aim of this study is to investigate whether the extract of sambiloto leaf can be used as a natural preservative for tomato and red chili, and to determine the concentration of extract of sambiloto leaf which is effectively used as the preservative. The method used in this study is maceration to produce extract and iodometric titration to determine the levels of vitamin $C$ before and after preservation. The results showed that the pickling tomatoes and red chili using extract of sambiloto leaf with a concentration of $6 \%$ sustained tomates up to 9 days and red chilies up to 11 days. Level of vitamin C contained in tomato is decreasing from $39.9 \mathrm{mg} / 100 \mathrm{~g}$ to $37.54 \mathrm{mg} / 100 \mathrm{~g}$ of material while red chilli is decreasing from $79.78 \mathrm{mg} / 100 \mathrm{~g}$ to $72.74 \mathrm{mg} / 100 \mathrm{~g}$ of material.
\end{abstract}

Keywords: Cooperative learning, jigsaw, NHT, stoichiometry

\section{Pendahuluan}

Bahan pangan merupakan kebutuhan dasar bagi manusia yang akan terus meningkat sesuai dengan laju pertumbuhan penduduk.Namun, bahan pangan akan mengalami perubahanperubahan yang tidak diinginkan seperti pembusukan dan ketengikan. Proses ini terjadi karena adanya reaksi kimia yang bersumber dari dalam dan luar bahan pangan tersebut (Purba, dkk., 2014). Bahan pangan mudah mengalami pembusukan karena adanya bakteri pembusuk. Pembusukan lebih cepat terjadi pada bahan pangan yang basah dan lembab. Hal ini terjadi karena kadar air yang tinggi yang terkandung dalam bahan pangan tersebut seperti halnya buah tomat dan cabai merah (Purwadi, dkk., 2007).

Tomat tergolong salah satu jenis sayuran yang sangat dikenal masyarakat. Rasanya yang manis-manis asam dapat memberikan kesegaran pada tubuh. Tomat juga termasuk sayuran

*Correspondence:

Widya Astuti Pusung

Program Studi Pendidikan Kimia, Fakultas Keguruan dan

Ilmu Pendidikan, Universitas Tadulako

email: widyaastutipusung@gmail.com

Published by Universitas Tadulako 2016 yang mudah ditanam dan bersifat responsiv terhadap berbagai perlakuan eksperimen. Namun, tomat juga merupakan salah satu jenis buah yang mudah mengalami pembusukan (Trisnawati, dkk., 2003). Selain tomat, cabai merah juga tidak kalah terkenal manfaatnya. Cabai merah dengan bentuk yang memanjang dan berwarna merah memiliki rasa yang pedas dan biasanya selalu ada pada setiap masakan khas Indonesia sebagai penambah rasa(Supriati \& Herliana, 2012). Rendahnya daya tahan (masa simpan) tomat dan cabai merah merupakan suatu masalah bagi petani dan penjual serta konsumen.Untuk menghindari hal ini, makanan sering ditambahkanpengawet. Pengawet ada dua jenis yaitu pengawet sintesis dan pengawet alami yang berfungsi membantu dan mempertahankan bahan makanan dari serangan mikroorganisme pembusuk bakteri dengan cara menghambat, mencegah, menghentikan proses pembusukan, fermentasi, pengasaman atau kerusakan komponen lain dari bahan pangan (Adawiyah, dkk., 1998).

Usaha yang pernah dilakukan untuk memperpanjang masa simpan produk hortikultura seperti tomat dan cabai merah 
adalah melapisi dengan lilin atau parafin. Penggunaan lilin atau parafin menyebabkan sayuran buah terlihat segar pada bagian luar, tetapi bagian dalam membusuk (Muarfah, 2008).Penggunaan bahan kimia sintetis sebagai pengawet dalam makanan sangat mengkhawatirkan, karena menyebabkan banyak masalah kesehatan dan masalah lingkungan (Purba, dkk., 2014). Oleh karena itu perlu adanya alternatif lain yang lebih aman digunakan sebagai bahan pengawet yaitu pengawet alami yang berasal dari alam yang banyak terdapat pada hampir semua tumbuhtumbuhan dan buah-buahan (Barus, 2009). Salah satunya adalah daun sambiloto.

Sambiloto termasuk salah satu tanaman obat unggulan Indonesia selain temulawak, mengkudu, lada, lidah buaya, dan kunyit. Sebagai tanaman unggulan, sambiloto ternyata sudah diteliti secara botani, budi daya, efek farmakologi, kandungan kimia dan uji klinis (Winarto, 2003).Kandungan utama dari daun sambiloto adalah diterpenoide lactones (andrographolide), paniculides, farnesols dan flavonoid. Selain itu, daun sambiloto mengandung saponin, alkaloid dan tanin. Kandungan kimia lain yang terdapat pada daun adalah lactone, paniculin, dan kalmegin (Dalimunthe, 2009). Secara farmakologi disebutkan daun sambiloto mempunyai sifat sebagai analgesik, antiinflamasi, antibakteri, antimikroba, antimalaria, antiviral, imunostimulator, hepatoprotektif, kardiovaskular, dan antikanker. Senyawa saponin mampu berperan sebagai pengawet alami karena dapat bekerja sebagai antimikroba yang akan merusak membran sitoplasma dan membunuh sel (Gotawa, dkk., 1999).

Saponin adalah suatu glikosida alamiah yang terikat dengan steroid atau triterpena. Saponin mempunyai aktivitas farmakologi yang cukup luas diantaranya meliputi immunomodulator, anti tumor, anti inflamasi, antivirus, anti jamur, dapat membunuh kerang-kerangan, hipoglikemik, dan efek hypokholesterol. Saponin juga mempunyai sifat bermacammacam, misalnya: terasa manis, ada yang pahit, dapat berbentuk buih, dapat menstabilkan emulsi, dapat menyebabkan hemolisis(Gotawa, dkk., 1999).

Vitamin C (asam askorbat) adalah vitamin yang sangat penting yang terkandung dalam buah dan sayur. Mengkonsumsi buah tidak hanya ingin merasakan kelezatan buah tersebut tapi untuk memperoleh vitamin yang terkandung di dalamnya yang tentunya sangat bermanfaat bagi tubuh kita untuk reaksi metabolisme dalam sel seperti vitamin C (Kumar, dkk., 2013).

Tulisan ini dimaksudkan untuk menginvestigasi ekstrak daun sambiloto dalam mempertahankan tekstur, warna dan kandungan vitamin $\mathrm{C}$ yang terkandung di dalamnya.

\section{METODE}

\section{Alat dan Bahan}

Alat-alat yang digunakan dalam penelitian ini atara lain wadah tempat daun sambiloto; tomat dan cabai merah; blender, neraca digital, spatula, tabung reaksi, gelas ukur, pipet tetes, stopwatch, mistar, pisau, erlenmeyer, aluminium foil, shaker, corong, kertas saring, gelas kimia, rotary evaporator, pompa vakum, labu ukur, buret, statif dan klem. Bahan utama yang digunakan adalah daun sambiloto, cabai merah, tomat, aquades, larutan $\mathrm{HCl} 2 \mathrm{M}$ (Merck), dan etanol 96\% (Merck), larutan amilum 1\% (Merck), larutan standar iodine 0,01 N (Ajax chemicals), dan aquades.

\section{Cara Kerja}

Pembuatan ekstrak daun sambiloto dilakukan dengan cara mencuci bersih daun sambiloto kemudian dikering anginkan selama 10 hari. Setelah kering daun tersebut dihaluskan menggunakan blender sampai diperoleh serbuk daun sambiloto. Serbuk tersebut ditimbang sebanyak 200 g. kemudian dilakukan uji busa saponin dengan cara memasukkan 0,5 g simplisia yang tersisa ke dalam tabung reaksi kemudian ditambahkan $10 \mathrm{~mL}$ aquades, mengocoknya hingga terbentuk busa dan ditambahkan 1 tetes larutan $\mathrm{HCl} 2 \mathrm{~N}$. setelah uji busa kemudian dilakukan maserasi selama 3 x 24 jam dengan cara menambahkan $600 \mathrm{~mL}$ pelarut etanol 96\% ke dalam $200 \mathrm{~g}$ serbuk daun sambiloto yang sudah ditimbang sebelumnya. Kemudian ekstrak disaring menggunakan pompa vakum dan filtratnya dievaporasi menggunakan rotary evaporator pada suhu $50^{\circ} \mathrm{C}$ dengan kecepatan 8 rpm. Kemudian ekstrak kering yang diperoleh dibuat variasi konsentrasi $0 \%, 2 \%$, 4\% dan 6\% dalam $100 \mathrm{~mL}$ larutan.

Proses pengawetan buah tomat dan cabai merah pertama-tama buah dicuci bersih dan ditiriskan. Kemudian buah-buah tersebut dicelupkan ke dalam larutan ekstrak selama 5 detik dan dibiarkan selama beberapa hari sampai pada penyimpanan optimal. Parameter mutu yang diamati adalah perubahan tekstur, warna dan kadar vitamin C sebelum dan sesudah pengawetan. Pengamatan perubahan tekstur menggunakan indera peraba, pengamatan 
perubahan warna menggunakan indera penglihatan dan penentuan kadar vitamin C dilakukan dengan cara buah ditimbang sebanyak $100 \mathrm{~g}$ dan dihaluskan menggunakan blender. Kemudian diambil $20 \mathrm{~g}$ sluri dan diencerkan hingga $100 \mathrm{~mL}$. Selanjutnya, larutan disaring hingga diperoleh filtratnya. $25 \mathrm{~mL}$ filtratdimasukkan ke dalam erlenmeyer dan ditambahkan dengan $20 \mathrm{~mL}$ aquades dan $2 \mathrm{~mL}$ amilum 1\%.Kemudian larutan tersebut dititrasi menggunakan larutan standar iodin $0,01 \mathrm{~N}$ sebagai titrannya.

\section{Hasil dan Pembahasan}

\section{Ekstraksi Daun Sambiloto}

Ekstrak daun sambiloto (A. paniculata [Burm.f] Nees)yang dihasilkan adalah 12,5 gram dari 200 gram serbuk daun sambiloto yang dimaserasi menggunakan pelarut etanol 96\% kemudian dievaporasi. Ekstrak kering tersebut kemudian dibuat 4 variasi konsentrasi yaitu $0 \%, 2 \%, 4 \%$ dan $6 \%$.

\section{Pengawetan Buah Tomat}

Pengawetan buah tomat menggunakan ekstrak daun sambiloto dapat dilihat pada Gambar 1

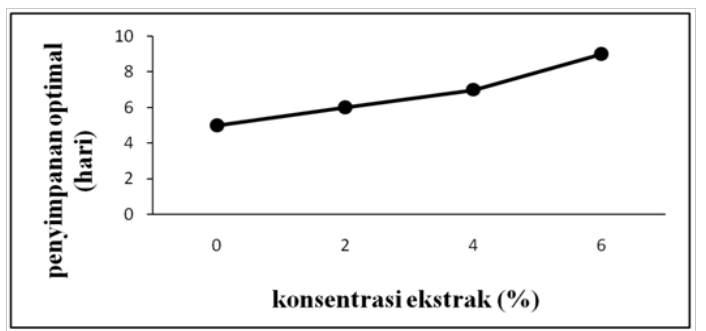

Gambar 1. Grafik hubungan antara konsentrasi ekstrak (\%) dan lama penyimpanan buah tomat (hari)

Pengawetan adalah teknik atau tindakan yang digunakan oleh manusia pada bahan pangan sedemikian rupa, sehingga bahan tersebut tidak mudah rusak. Pengawetan mencegah terjadinya kerusakan tetapi lebih tepat dikatakan menghambat kerusakan karena secara lambat atau cepat yang diawetkan akan mengalami kerusakan (Ningsih, 2010).

Proses pengawetan buah tomat dilakukan dengan cara mencelupkan buah tomat ke dalam larutan ekstrak $0 \%, 2 \%, 4 \%$, dan $6 \%$ selama 5 detik. Dengan pencelupan ini, maka ekstrak daun sambiloto dapat melapisi kulit luar buah tomat. Proses pencelupan tidak boleh terlalu lama, karena akan menyebabkan ekstrak masuk ke bagian dalam buah tomat yang nantinya akan mempengaruhi rasa dari buah tersebut. Setelah dicelupkan, buah tomat dibiarkan selama beberapa hari dan diamati perubahannya setiap hari. Buah tomat yang diawetkan dengan ekstrak 2\% memiliki masa simpan paling lama 6 hari, lebih lama 1 hari dari kontrol. Ekstrak 4\% memiliki masa simpan 7 hari, lebih lama 2 hari dari kontrol dan ekstrak 6\% memiliki masa simpan 9 hari, lebih lama 4 hari dari kontrol. Hasil tersebut menunjukkan bahwa ekstrak daun sambiloto dapat menghambat laju pemasakan dan pembusukan buah tomat. Proses pemasakan pada buah disebabkan adanya metabolisme lanjutan setelah panen, terutama respirasi dan transpisari (Muarfah, 2008).

\section{Hubungan Lama Penyimpanan dan Jumlah Tomat yang Lembek}

Jumlah buah tomat yang mengalami perubahan tekstur bertambah setiap harinya selama masa penyimpanan. Adapun perubahan jumlah tersebut data dilihat pada Gambar 2 berikut ini.

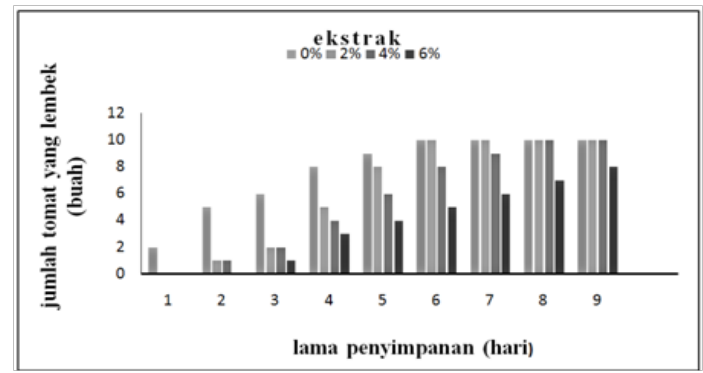

Gambar 2. Grafik hubungan antara lama penyimpanan (hari) dan jumlah tomat yang lembek (buah)

Buah tomat yang digunakan berjumlah 10 buah dengan tingkat kematangan yang hampir sama. Setiap hari terjadi perubahan tekstur yang berbeda-beda pada tomat-tomat tersebut. Berdasarkan grafik hubungan antara lama penyimpanan dan jumlah tomat yang lembek dapat diketahui bahwa pada hari pertama pengawetan untuk ekstrak 0\% (kontrol) buah sudah mengalami perubahan tekstur sedangkan ekstrak yang lain belum mengalami perubahan. Hari ke-2 kontrol mengalami perubahan tekstur yang lebih banyak dan ekstrak 2\% dan 4\% sudah mengalami perubahan walaupun hanya 1 buah sedangkan ekstrak 6\% belum mengalami perubahan. Ekstrak 6\% mengalami perubahan pada hari ke-3.Hal ini menunjukkan bahwa untuk konsentrasi 0\% lebih cepat mengalami perubahan tekstur dibandingkan konsentrasi $2 \%$, 4\%, dan 6\%. Sedangkan yang paling lama mengalami perubahan tekstur adalah ekstrak 6\%. Hasil pengawetan menggunakan ekstrak daun sambiloto menunjukkan bahwa semakin lama buah tomat tersebut disimpan, maka terjadi perubahan tekstur.Pada awalnya 
buah tomat masih keras dan berangsur-angsur menjadi lembek dan akhirnya menjadi sangat lembek. Perubahan ini disebabkan oleh zat-zat organik yang terkandung dalam buah tomat pada proses metabolisme. Senyawa organik yang bobot molekulnya besar terurai menjadi senyawa yang berbobot molekul rendah (Muarfah, 2008).।

\section{Perubahan Warna Buah Tomat}

Perubahan warna yang terjadi pada buah tomat selama pengawetan dapat dilihat pada Tabel 1 berikut ini.

Keterangan : MK1 = merah kekuningan; $\mathrm{M}$

Tabel 1. Perubahan warna pada buah tomat selama proses pengawetan

\begin{tabular}{ccccccccccc}
\hline Konsentrasi & \multicolumn{10}{c}{ Hari ke- } \\
\cline { 2 - 9 } ekstrak $(\%)$ & 0 & 1 & 2 & 3 & 4 & 5 & 6 & 7 & 8 & 9 \\
\hline 0 & $\mathrm{MK}_{1}$ & $\mathrm{MK}_{1}$ & $\mathrm{M}$ & $\mathrm{M}$ & $\mathrm{M}$ & $\mathrm{MK}_{2}$ & $\mathrm{MK}_{2}$ & $\mathrm{MK}_{2}$ & $\mathrm{MK}_{2}$ & $\mathrm{MK}_{2}$ \\
2 & $\mathrm{MK}_{1}$ & $\mathrm{MK}_{1}$ & $\mathrm{M}$ & $\mathrm{M}$ & $\mathrm{M}$ & $\mathrm{M}$ & $\mathrm{MK}_{2}$ & $\mathrm{MK}_{2}$ & $\mathrm{MK}_{2}$ & $\mathrm{MK}_{2}$ \\
4 & $\mathrm{MK}_{1}$ & $\mathrm{MK}_{1}$ & $\mathrm{MK}_{1}$ & $\mathrm{M}$ & $\mathrm{M}$ & $\mathrm{M}$ & $\mathrm{MK}_{2}$ & $\mathrm{MK}_{2}$ & $\mathrm{MK}_{2}$ & $\mathrm{MK}_{2}$ \\
6 & $\mathrm{MK}_{1}$ & $\mathrm{MK}_{1}$ & $\mathrm{MK}_{1}$ & $\mathrm{M}$ & $\mathrm{M}$ & $\mathrm{M}$ & $\mathrm{M}$ & $\mathrm{M}$ & $\mathrm{MK}_{2}$ & $\mathrm{MK}_{2}$ \\
\hline
\end{tabular}

= merah; $\mathrm{MK} 2$ = merah kecoklatan .

Berdasarkan tabel di atas diperoleh hasil bahwa buah tomat berubah dari warna merah kekuningan menjadi merah seiring lama penyimpanan dan lama kelamaan berubah menjadi merah kecoklatan ketika sudah mencapai proses pembusukan. Ekstrak 0\% dan $2 \%$ dapat mempertahankan warna merah kekuningan selama 1 hari dan mengalami perubahan warna menjadi merah pada hari ke-2 sampai hari ke-4 untuk ekstrak 0\% dan sampai hari ke-5 untuk ekstrak 2\% dan mengalami perubahan lagi pada hari ke-5 untuk ekstrak $0 \%$ dan pada hari ke-6 untuk ekstrak 2\% menjadi warna merah kecoklatan. Sedangkan ekstrak 4\% dan 6\% mengalami perubahan warna dari merah kekuningan menjadi merah pada hari ke-3 dan terjadi perubahan warna dari merah menjadi merah kecoklatan pada hari ke-6 untuk ekstrak 4\% dan hari ke-8 untuk ekstrak $6 \%$.

Buah tomat berubah warna dari merah kekuningan menjadi merah seiring lama waktu pengawetan. Tomat merupakan sumber utama likopen(Giovannucci, dkk., 2002). Likopen ialah suatu karotenoid pigmen merah terang yang banyak ditemukan dalam buah tomat dan buah-buahan lain yang berwarna merah merupakan salah satu antioksidan yang sangat kuat. Selain sebagai anti skin aging, lycopene juga memiliki manfaat untuk mencegah penyakit cardiovascular(Rizqy, 2011).

\section{Kadar Vitamin C Buah Tomat}

Kadar vitamin $C$ pada buah tomat dapat dilihat pada Tabel 2 berikut ini.

Buah-buahan mengandung air, karbohidrat, asam-asam, protein, lemak, mineral, pigmen
Tabel 2. Hasil Analisis Kadar Vitamin C pada Buah Tomat

\begin{tabular}{|c|c|c|c|}
\hline \multicolumn{2}{|c|}{ Keadaan Buah } & $\begin{array}{c}\text { Lama Penyimpanan } \\
\text { (hari) }\end{array}$ & $\begin{array}{l}\text { Kadar Vitamin C } \\
(\text { mg }) / 100 \text { g bahan }\end{array}$ \\
\hline \multirow{2}{*}{ Tomat } & $\begin{array}{c}\text { Sebelum } \\
\text { Pengawetan }\end{array}$ & 0 & 39,9 \\
\hline & $\begin{array}{l}\text { Penyimpanan } \\
\text { Optimal }(6 \%)\end{array}$ & 9 & 37,54 \\
\hline
\end{tabular}

dan vitamin.Pada buah tomat vitamin yang komposisinya cukup besar adalah vitamin C. Struktur vitamin C tertera pada Gambar 3.<smiles>O=C1OC(C(O)CO)C(O)=C1O</smiles>

Gambar 3. Struktur Vitamin C

Buah tomat pada penyimpanan optimal yaitu ekstrak 6\% selama 9 hari mengalami penurunan kadar vitamin C dari 39,9 mg/100 $\mathrm{g}$ bahan menjadi $37,54 \mathrm{mg} / 100 \mathrm{~g}$ bahan. Penurunan kadar vitamin C akan terjadi pada buah yang diawetkan dengan konsentrasi berapapun. Buah tomat yang belum masak memiliki kadar vitamin C yang lebih besar. Kadar vitamin $\mathrm{C}$ akan menurun seiring tingkat kematangan buah karena mengalami proses metabolisme (Apandi, 1984).

\section{Pengawetan Cabai Merah}

Ekstrak daun sambiloto memberikan masa simpan yang berbeda-beda terhadap cabai merah tergantung dari seberapa besar ekstrak daun sambiloto yang digunakan. Adapun pengaruh tersebut dapat dilihat pada Gambar 4 berikut ini.

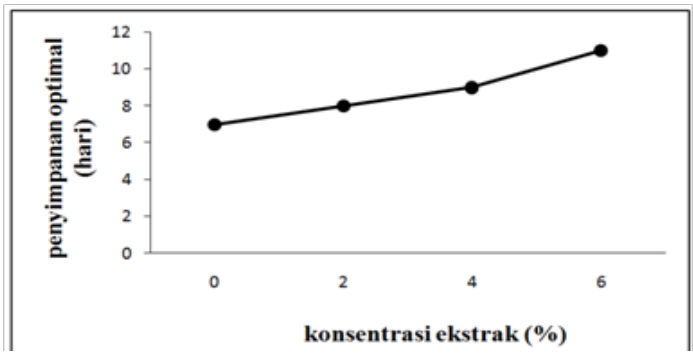

Gambar 4.Grafik hubungan antara

konsentrasi ekstrak dan lama penyimpanan cabai merah

Cabai merah yang diawetkan dengan ekstrak daun sambiloto memiliki masa simpan 
yang bervariasi tergantung dari ekstrak yang digunakan. Ekstrak 0\% dapat mengawetkan cabai merah selama 7 hari, ekstrak $2 \%$ dapat mengawetkan selama 8 hari, ekstrak 4\% dapat mengawetkan selama 9 hari dan ekstrak 6\% dapat mengawetkan cabai merah paling lama yaitu selama 11 hari. Hal tersebut menunjukkan bahwa ekstrak daun sambiloto dapat menghambat laju pemasakan pada cabai merah. Proses pemasakan pada buah disebabkan adanya metabolism lanjutan setelah panen, terutama respirasi dan transpirasi.

\section{Hubungan Lama Penyimpanan dan Jumlah} Cabai Merah yang Lembek

Jumlah cabai merah yang mengalami perubahan tekstur bertambah setiap harinya selama masa penyimpanan. Adapun perubahan jumlah tersebut dapat dilihat pada Gambar 5 berikut ini.

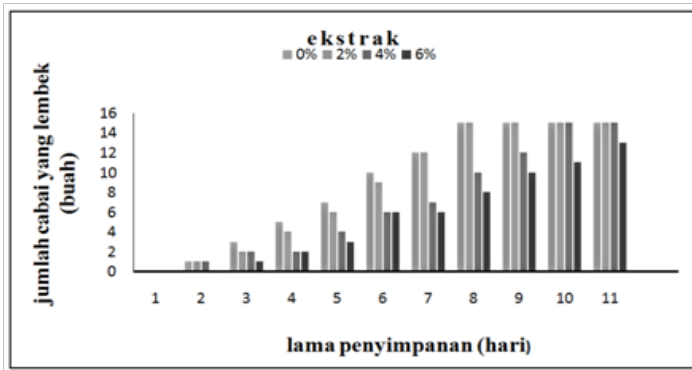

Gambar 5. Grafik hubungan antara lama penyimpanan (hari) dan jumlah cabai merah yang lembek dan mengerut (buah)

Berdasarkan grafik hubungan antara lama penyimpanan dan jumlah cabai merah yang lembek dapat diketahui bahwa tidak terjadi perbedaan yang signifikan dalam perubahan tekstur cabai setiap harinya antara masingmasing ekstrak.Hari pertama semua cabai belum mengalami perubahan. Hari ke-2 selain ekstrak 6\% sudah mengalami perubahan yang sama yaitu 1 buah cabai lembek. Sedangkan ekstrak 6\% mengalami perubahan pada hari ke-3.Berdasarkan data tersebut terlihat bahwa kontrol yang lebih cepat mengalami perubahan dibandingkan ekstrak yang menggunakan daun sambiloto.Hal ini terjadi karena dalam larutan kontrol tidak mengandung senyawa saponin yang berfungsi sebagai antibakteri.Sedangkan ekstrak 6\% adalah ekstrak yang dapat mempertahankan tekstur cabai dengan masa simpan yang lebih lama.Hal ini terjadi karena ekstrak 6\% mengandung senyawa saponin yang lebih banyak dibandingkan dengan ekstrak $2 \%$ dan $6 \%$.

Hasil pengawetan dengan ekstrak daun sambiloto menunjukkan bahwa semakin lama cabai merah tersebut disimpan maka terjadi perubahan struktur yang awalnya keras lamakeamaan menjadi lembek. Perubahan ini terjadi karena penguraian zat-zat organik yang terkandung dalam cabai merah dalam proses metabolisme. Senyawa organik yang bobot molekulnya besar terurai menjadi senyawa yang berbobot molekul rendah.

Protopektin yang terkandung pada buah yang belum masak lebih banyak daripada buah yang telah masak.Buah yang telah masak teksturnya menjadi lembek karena protopektin berubah menjadi senyawa pektin yang dapat larut. Pelunakan buah disebabkan degradasi protopektin tidak larut menjadi pektin yang larut (Sumadi, dkk., 2004).

\section{Warna Cabai Merah}

Perubahan warna yang terjadi pada cabai merah selama pengawetan dapat dilihat pada Tabel 3 berikut ini.

Tabel 3. Perubahan warna pada cabai merah selama proses pengawetan

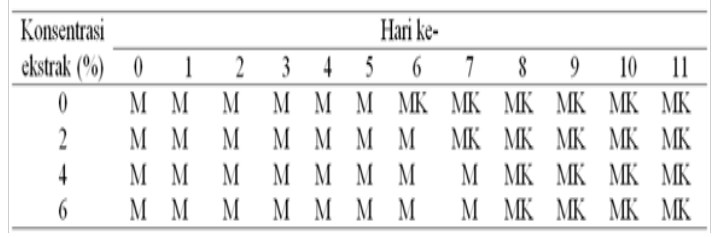

Keterangan : $\mathrm{M}=$ merah; $\mathrm{MK}=$ merah kecoklatan

Berdasarkan tabel di atas dapat diketahui bahwa semua cabai merah yang dicelukan ke dalam masinh-masing konsentrasi ekstrak dapat mempertahankan warna merah sampai pada hari ke-5. Sedangkan pada hari ke-6 untuk konsentrasi $0 \%$ sudah mengalami perubahan warna menjadi merah kecoklatan. Hal ini terjadi karena cabai merah sudah mengalami proses pembusukan. Sedangkan untuk konsentrasi yang lain belum mengalami perubahan. Pada hari ke-7 untuk konsentrasi $2 \%$ mengalami perubahan warna menjadi merah kecoklatan dan hari ke-8 semua cabai merah sudah mengalami perubahan warna menjadi merah kecoklatan.

Perubahan penampilan pada buah, baik warna, tekstur, bau dan rasa membuat kurang diminati untuk dikonsumsi, hal ini disebut bahwa buah sudah mencapai proses pembusukan makanan (Aneja, dkk., 2014). Cabai sering digunakan dalam masakan, selain itu tumbuhan ini juga menjadi sumber nutrisi yang penting bagi manusia terutama sebagai sumber vitamin A dan C dan senyawasenyawa fenol asam dan netral(Setiadi, 1994). 
Ekstrak cabai yang mengandung karotenoid, mempunyai aktifitas antioksidan yang tinggi dalam menghambat reaksi radikal bebas. Cabai merah memiliki warna merah terutama selama penuaan buah yang berasal dari pigmen karotenoid. Umumnya konsentrasi karotenoid, asam askorbat, flavonoid, phenolic acids, dan komponen kimia lainnya meningkat dengan meningkatnya umur lombok kecuali lutein yang mengalami penurunan(Susilowati., 2008). Beberapa jenis karotenoid yang banyak terdapat di alam dan bahan makanan adalah $\beta$-karoten (berbagai buahbuahan yang kuning dan merah), likopen (tomat), kapxantin (cabai merah), dan biksin (annatis)(Maforimbo, 2002).

\section{Kadar Vitamin C Cabai Merah}

Kadar vitamin $C$ padaCabai Merah dapat dilihat pada Tabel 4 berikut ini.

Tabel 4. Hasil Analisis Kadar Vitamin C pada Cabai Merah

\begin{tabular}{cccc}
\hline Keadaan Buahl & $\begin{array}{c}\text { Lama Penvimpanan } \\
\text { (hari) }\end{array}$ & $\begin{array}{c}\text { Kadar Vitamin C } \\
\text { (mg) } 100 \mathrm{~g} \text { bahan }\end{array}$ \\
\hline \multirow{2}{*}{ Cabai Merah } & $\begin{array}{c}\text { Sebelum } \\
\text { Pengawetan }\end{array}$ & 0 & 79,78 \\
& $\begin{array}{l}\text { Penvimpanan } \\
\text { Optimal (6\%) }\end{array}$ & 11 & 72,74 \\
\hline
\end{tabular}

Cabai merah pada penyimpanan optimal yaitu ekstrak 6\% selama 11 hari mengalami penurunan kadar vitamin $\mathrm{C}$ yaitu dari 79,78 $\mathrm{mg} / 100 \mathrm{~g}$ bahan menjadi $72,74 \mathrm{mg} / 100 \mathrm{~g}$ bahan. Penurunan kadar vitamin $\mathrm{C}$ akan terjadi pada buah yang diawetkan dengan konsentrasi berapapun. Cabai merah yang belum masak memiliki kadar vitamin $C$ yang lebih besar. Kadar vitamin $\mathrm{C}$ akan menurun seiring tingkat kematangan buah karena mengalami proses metabolisme. Vitamin C sangat peka terhadap oksidasi jika tidak ditangani dengan hati-hati. Asam askorbat akan berkurang karena sangat peka terhadap oksidasi oleh adanya asam askorbat oksidase yang terdapat pada jaringan tanaman (Apandi, 1984).

\section{Kesimpulan}

Ekstrak daun sambiloto dapat digunakan sebagai bahan pengawet alami pada buah tomat dan cabai merah, karena dapat memperpanjang masa simpan buah-buah tersebut dengan mempertahankan tekstur dan warna lebih lama dari kontrol. Ekstrak daun sambiloto yang paling lama mempertahankan masa simpannya adalah 6\% dengan masa simpan 9 hari untuk buah tomat dan 11 hari untuk cabai merah.

\section{Ucapan Terima Kasih}

Penulis mengucapkan terima kasih kepada Kepala Laboratorium Agroteknologi Fakultas Pertanian dan semua pihak yang telah membantu dalam proses penelitian ini.

\section{Referensi}

Adawiyah, R., Soekarno., \& Jenie, B. (1998). Ekstraksi komponen antimikroba dari bijih buah atung. Prosiding Seminar Nasional Teknologi Pangan dan Gizi, Yogyakarta.

Aneja, K. R., Dhiman, R., Aggarwal, N. K., \& Aneja, A. (2014). Emerging preservation techniques for controlling spoilage and pathogenic microorganisms in fruit juices. International Journal of Microbiology, 2014, $1-14$.

Apandi, M. (1984). Teknologi buah dan sayur. Bandung: Alumni.

Barus, P. (2009). Pemanfaatan bahan pengawet dan antioksidan alami pada industri bahan makanan.Pidato Pengukuhan Jabatan Guru Besar Tetap dalam Bidang Ilmu Kimia Analitik pada Fakultas Matematika dan Ilmu Pengetahuan Alam, diucapkan dihadapan Rapat Terbuka, Universitas Sumatera Utara, Medan.

Dalimunthe, A. (2009). Interaksi sambiloto (andrographis paniculata). Departemen Farmakologi Fakultas Farmasi Universitas Sumatera Utara, Medan

Giovannucci, E., Rimm, E., Liu, Y., Stampfer, M., \& Willent, W. (2002). A prospective study of tomato product, lycopene, and prostate cancer risk. Journal of the National Cancer Institute, 94(5), 391-398.

Gotawa, I., Sugiarto, S., Nurhadi, M., Widiyastuti, Y., Wahyono, S., \& Prapti, I. (1999). Inventaris tanaman obat indonesia jilid V. Jakarta: Departemen Kes. Badan Penelitian dan Pengembangan Kesehatan.

Kumar, G. V., Kumar, A. K., Patel, R. G. R., \& Manjappa, S. (2013). Determination of vitamin c in some fruits and vegetables in Davanagere city Karanataka India. 
International Journal of Pharmacy \& Life Sciences, 4(3), 2489-2491.

Maforimbo, E. (2002). Evaluation of capsicum as a source of natural antioxidant in preventing rancidity in sunflower oil. The Journal of Food Technology in Africa, 7, 6872.

Muarfah, S. (2008). Isolasi kitosan pada limbah udang dan aplikasinya pada pengawetan buah tomat dan jeruk manis. Skripsi, Universitas Tadulako.

Ningsih, W. A. (2010). Ekstrak kitosan dari limbah udang berdasarkan derajat deasetilasinya dan aplikasinya sebagai pengawet pada wortel dan kentang. Skripsi, Universitas Tadulako.

Purba, R., Suseno, S. H., Izaki, A. F., \& Muttaqin, S. (2014). Application of liquid smoke and chitosan as natural preservatives for tofu and meatballs. International Journal of Applied Science and Technology, 4(2), 212217.

Purwadi, A., Usada, W., \& Isyuniarto. (2007). Pengaruh lama waktu ozonisasi terhadap umur simpan buah tomat (lycopersicum esculentum mill). Prosiding PPI-PDIPTN Pustek Akselerator dan Proses Bahan-
BATAN Yogyakarta.

Rizqy, A. (2011).Analisakadarlikopenpadabuah tomat dengan menggunakan spektrofotometer. Tugas Akhir Program Studi Diploma III Teknik Kimia Program Diploma Fakultas Teknik, Universitas Diponegoro, Semarang.

Setiadi. (1994). Bertanam cabai. Jakarta: Penebar Swadaya.

Sumadi, B., Sugiharto, \& Suyanto. (2004). Metabolisme sukrosa pada proses pemasakan pisang yang diperlakukan pada suhu berbeda. Jurnal Ilmu Dasar, 5(1), 2126.

Supriati, Y., \& Herliana, E. (2012). Bertanam 15 sayuran organik dalam pot. Jakarta: Penebar Swadaya.

Susilowati. (2008). Isolasi dan identifikasi senyawa karotenoid dari cabai merah (capsicum annuum L.). Skripsi, Universitas Islam Negeri Malang.

Trisnawati, Y., Setiawan., \& Iwan, A. (2003). Tomat pembudidayaan secara komersial. Jakarta: Penebar Swadaya.

Winarto, W. P. (2003). Sambiloto. Jakarta: Penebar Swadaya. 